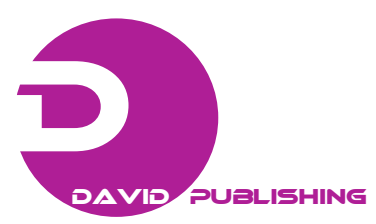

\title{
Predictive Analysis of Landslide Susceptibility with GIS-DEMs in Uyo, South Eastern Nigeria
}

\author{
Charles Udosen ${ }^{1}$, Abasi-Ifreke S. Etok ${ }^{2}$ and Aniesua Essiett ${ }^{3}$ \\ 1. Department of Geography and Natural Resources, University of Uyo, Nigeria \\ 2. College of Arts and Science, Nung Ukim, Ikono \\ 3. Department of Physics, University of Uyo, Nigeria
}

\begin{abstract}
Landslides are ubiquitous geomorphic features in the loose/weakly cemented soils formed from the coastal plains sands in different parts of southeastern Nigeria due to widespread gully erosion resulting from infrequent occurrence of high intensity and prolonged rainstorms during the peak of wet season (June-September). In this area, landslides occur mostly as earth movement, mud flow, and debris flows on slopes previously weakened by flood water. GIS (Geographic Information System) was employed as a system with advanced geo-modeling capabilities combined with field observation which were used in this study to map potential areas of landslides in Uyo town, Akwa Ibom State in southeastern Nigeria. The study generated a landslide zonation map highlighting areas of different degrees of susceptibility elevation in meters. Slope surface in degrees was also generated and reclassified into three slope classes (uniform, gentle and steep) using the same reclassification algorithm. The result indicates that $89,583 \mathrm{~m}^{2}$ representing $10.59 \%$ of the total catchment of $845,918 \mathrm{~m}^{2}$ is highly susceptible to landslides.
\end{abstract}

Key words: DEM, landslide, GIS, Uyo, slope.

\section{Introduction}

The development of most of towns and villages in Nigeria occurred without any systematic planning; buildings sprang up without any recourse to physical planning particularly during evolution of traditional urbanization in the late 18th century. In the study area, most landslide scars are associated with accelerated soil erosion have been an issue of growing concern not only in the humid tropics but in many parts of the world. Many published studies exist on the occurrence, assessment and monitoring of this phenomenon in an urban environment in the temperate region [1]; in Santa Cruz Island, California [2]; in southeastern Nigeria [3]; in mountainous environment [4]; in northeast Kansas, USA [5]; in Europe [6]. This issue is so important because the collapse of slopes due to landslides, as well as the head-ward and lateral progression, releases large amounts of sediments and

Corresponding author: Charles Udosen, Snr Lecturer, Fluvial Geomorphologist and GIS pundit. E-mail: charlesudosen@gmail.com. can enhance rates of overall landscape lowering and evolution [7-9]. This may also result in increased sedimentation and water quality problems in many drainage basins. In addition, several buildings and infrastructures have been destroyed in some cases and public services have been disrupted by devastating landslides in urban centres [10]. Hence, there has been considerable research on understanding of landslide development, but much of this effort has been on evaluation of landslides in both European and American countries.

There is paucity of knowledge on landslide modeling in Nigeria, except perhaps the study reported by Igbokwe et al. [3]. In the current study, GIS (Geographic Information System) was deployed to capture, store, manipulate and analyze terrain data of landslide prone valley slopes of an order- 1 stream in Uyo uran area of Akwa Ibom State, Nigeria. The GIS was also used to generate 3D models of the study area. 


\section{Background Information on Study Area}

Uyo, the capital of Akwa Ibom State (Fig. 1), is located between latitudes $4^{0} 54^{1} \mathrm{~N}$ and $5^{\circ} 03^{1} \mathrm{E}$ and longitudes $7^{\circ} 57^{1} \mathrm{~N}$ and $8^{\circ} 03^{1} \mathrm{E}$. The study area has climate characteristics that could be described as humid tropical, i.e., Af climate type based on Koppen's classification. There are two main seasons - the dry season (November to February/March) when the northeast trade wind from the desert blows across the area. The rains come between March and October (and in some wet years it may extend into early November, when the ITD moves southwards [10]).

As illustrated in Fig. 2, the mean annual rainfall in Uyo is 2,466.6 mm, recorded between 1977 and 2010. The wettest year during this period was 1977, which had a rainfall of $3,855.8 \mathrm{~mm}$. The driest year, on the other hand, was 1983 with a total annual rainfall of $1,599.4 \mathrm{~mm}$. The distribution of extreme rainstorms is shown in Table 1.

The values for relative humidity range from $56 \%$ to $87 \%$, with a mean of $67.8 \%$. Often, December, January and February are months with the highest values. These months depict the peak of the dry season, with limited moisture in the atmosphere [10]. The wind speed ranges from zero to about $4.5 \mathrm{~m} / \mathrm{s}$, with a mean of $2.5 \mathrm{~m} / \mathrm{s}$ at Uyo. The study area is underlain by one main geological formation, the coastal plains sands comprising largely of poorly consolidated sands and sandstones as exposed in the upper course of Ikpa river system. The sands which make up by far the greater part of the deposits, possess several characteristics which are always present where
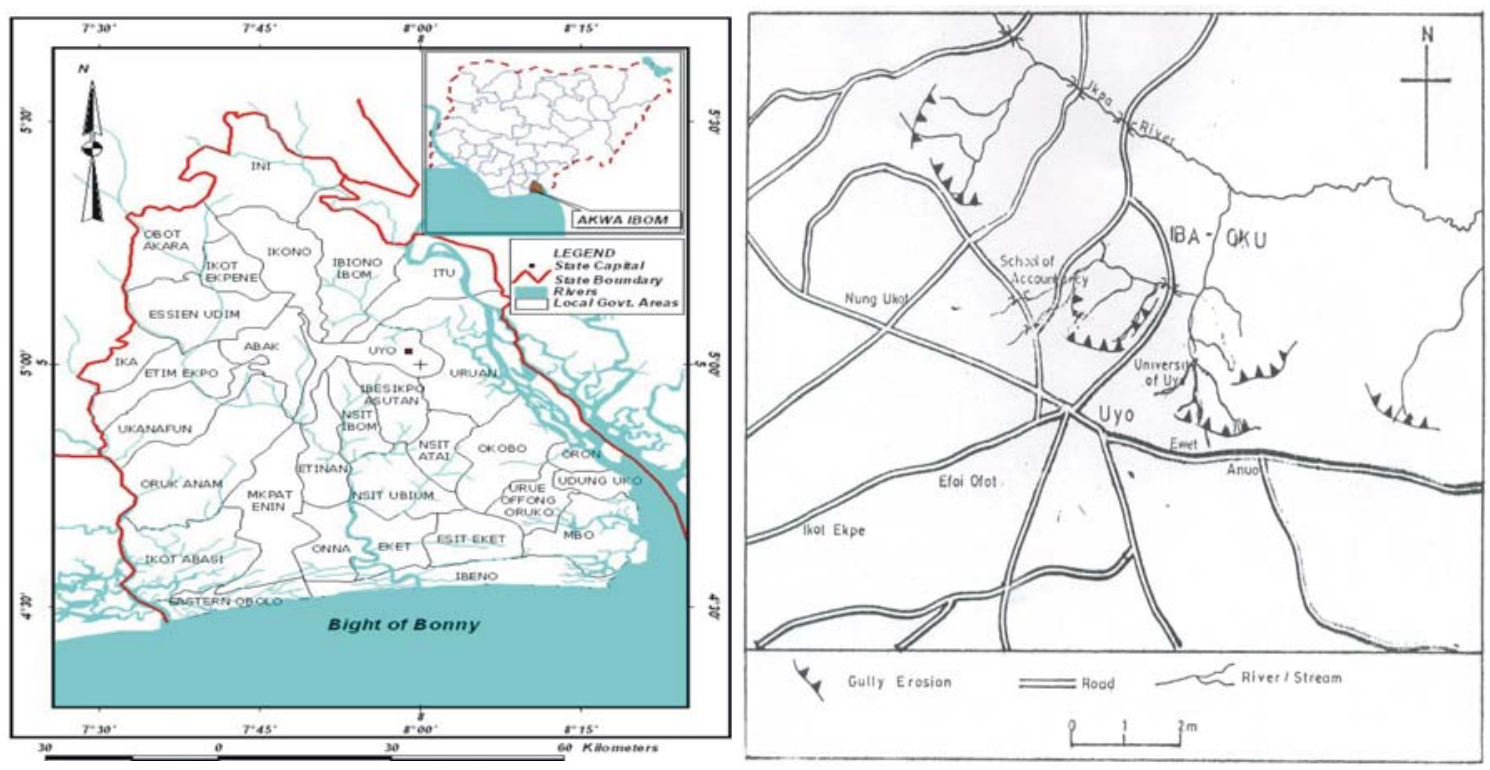

Fig. 1 Map of Akwa Ibom State showing the location of Uyo City.

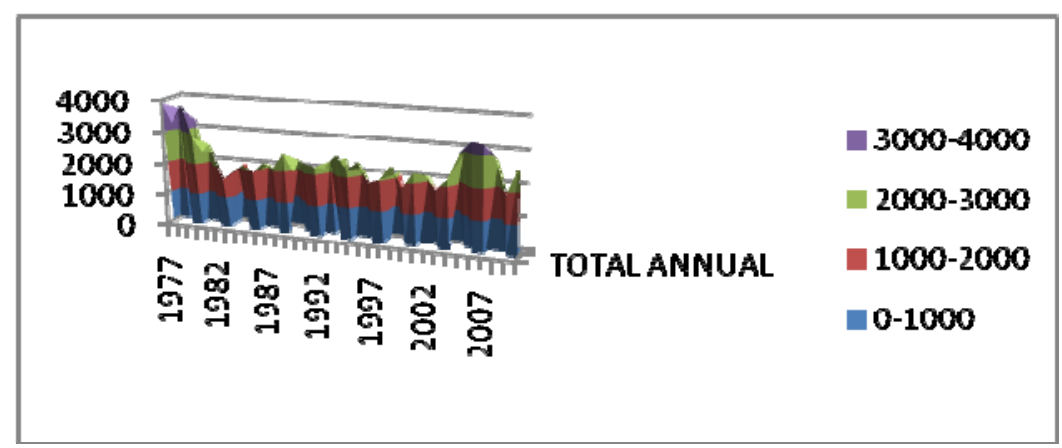

Fig. 2 Rainfall distribution in Uyo, Nigeria (1977-2010). 
Table 1 Extreme rainfall series in Uyo (1979-2010).

\begin{tabular}{|c|c|c|c|}
\hline Year & $\begin{array}{l}\text { Annual total } \\
(\mathrm{mm})\end{array}$ & Days & $\begin{array}{l}\text { Extreme rainfall } \\
\text { amount (mm) }\end{array}$ \\
\hline 1979 & $3,825.4$ & April 22 & 180.0 \\
\hline 1980 & $2,860.4$ & August 22 & 106.4 \\
\hline 1981 & $2,426.8$ & September 6 & 110.3 \\
\hline 1982 & $2,442.5$ & June 11 & 93.9 \\
\hline 1983 & $1,599.5$ & July 16 & 61.6 \\
\hline 1984 & $1,878.9$ & June 25 & 66.2 \\
\hline 1985 & $2,132.6$ & September 18 & 94.6 \\
\hline 1986 & $1,905.2$ & July 10 & 74.0 \\
\hline 1987 & $2,251.4$ & May 30 & 76.7 \\
\hline 1988 & $2,115.0$ & September 15 & 113.8 \\
\hline 1989 & $2,588.7$ & July 8 & 115.1 \\
\hline 1990 & $2,027.1$ & August 10 & 114.0 \\
\hline 1991 & $2,346.7$ & April 27 & 92.6 \\
\hline 1992 & $2,256.8$ & August 11 & 119.3 \\
\hline 1993 & 2,229.5 & August 11 & 118.8 \\
\hline 1994 & $2,668.7$ & June 27 & 110.1 \\
\hline 1995 & $2,264.4$ & October 27 & 78.0 \\
\hline 1996 & $2,520.7$ & August 19 & 120.0 \\
\hline 1997 & $1,921.3$ & October 26 & 100.4 \\
\hline 1998 & $2,033.8$ & June 7 & 100.0 \\
\hline 1999 & $2,508.5$ & October 29 & 90.0 \\
\hline 2000 & $1,840.8$ & October 26 & 100.4 \\
\hline 2001 & $2,317.2$ & June 21 & 82.1 \\
\hline 2002 & $2,301.5$ & September 13 & 110.0 \\
\hline 2003 & $1,894.3$ & October 7 & 70.4 \\
\hline 2004 & $2,221.6$ & September 5 & 135.5 \\
\hline 2005 & $3,030.5$ & July 2 & 161.2 \\
\hline 2006 & 3,373.7 & September 10 & 151.0 \\
\hline 2007 & $3,308.2$ & October 10 & 117.6 \\
\hline 2008 & $2,970.6$ & June 15 & 130.0 \\
\hline 2009 & $1,944.1$ & April 21 & 155.0 \\
\hline 2010 & 2,732.6 & August 23 & 148.4 \\
\hline
\end{tabular}

Source: analysed from rainfall data, Agrometeorological Station, University of Uyo, 2011.

good exposures are found especially in deep gully channels. The study area has a base level of $11 \mathrm{~m}$, basin relief of $56 \mathrm{~m}$ and maximum elevation of $77 \mathrm{~m}$ above mean sea level, but the ground slope is imperceptibly in a south-north eastwards direction as evidenced by the flow direction of drainage systems. Most of these rivers are order -1 streams with high potential energy to evacuate the sediments washed from deep gully channels ravaging the north-eastern part of Uyo urban. These gullies often riddle long rectilinear valley slopes. In most cases, extensive gully erosion problems may lead to loss of valuable agricultural soil (as farmlands are cut into odd shaped parcels of land) and infrastructures are under constant threat.

In addition to the human factors of gully development, there are several drainage basin parameters that may induce rapid incision and development of gullies in the study area. These include the geological formation-loose incoherent coastal plains sands of fluvio-marine origin that lack cementing agents due to low rock mineral content, the build-up of organic matter is critical in binding the loose, unconsolidated earth materials together. Similarly the soils formed from the coastal plains sands are mainly porous sand particles, with less clay. These soils have weak structure that easily collapses during high intensity rainstorms. Hence, in the study site, the balance between the unconsolidated soils and vegetation cover is very delicate, removal of vegetation leads to devastating gullies particularly on steep valley slopes of 1 ts order streams.

\section{Materials and Methods}

In order to generate 3D models of study area (at Dominic Utuk Avenue, Uyo), a Germin e-trex GPS (global positioning system) receiver was configured to capture terrain information using world UTM (universal transverse Mercator) 1984 latlong geographic coordinate system with elevation values in meters. This GPS receiver was used to collect point data (waypoints) of the valley slopes on an average spatial

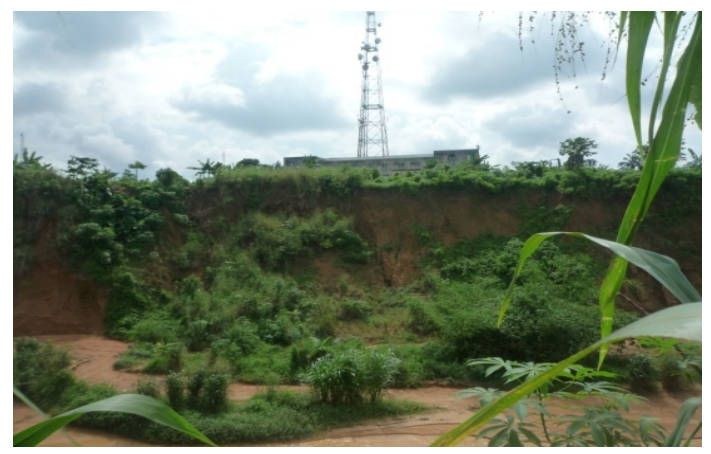

Fig. 3 Extensive landslide site at Uyo City. 
resolution of $3.5 \mathrm{~m}$. A total of 236 waypoints representing spot heights spread across the study site were generated. Based on Ref. [11], the values of spot heights were plotted against the coordinates of each point in Surfer 8.0 software. IDW (Inverse Distance Weighting) interpolation method was used in converting the spot heights to a Surfer grid. This is a smooth surface of 100 rows by 92 columns. IDW uses surrounding measurements to forecast values for unmeasured points. In this method, values closest to the prediction points have greater influence on the interpolated values than those farther away and for each predicted value, a minimum of 2 and a maximum of 12 surrounding points were used to predict the value [11]. The Surfer grid was then as input data for mapping the 3D model of the study area that can be viewed in different perspectives. This figure was mapped using orthographic projection; field of view put at angle $45^{\circ}$, rotated at angle $45^{\circ}$ and tilted at $30^{\circ}$ from its axis. To give a clearer view of the site, a different scenario was mapped using perspective projection; field of view put at angle $90^{\circ}$, rotated at angle $260^{\circ}$ and tilted at $90^{\circ}$ from its axis. In order to generate other composite layers (contour and slope) for effective evaluation of landslides, the spot heights were also converted to Esri grid of pixel resolution of 3.52 by 3.52 m using Spatial Analyst Extension of Arc GIS 9.3 software. Using Natural Breaks (Jenks) algorithm, the generated contour layer was reclassified into five major relief classes based on their elevation in meters (15-28; 29-40; 41-50; 51-58; and 59-74). Similarly, slope surface in degrees was also generated and reclassified into three slope classes (uniform, gentle and steep) using the same reclassification algorithm. Further analysis to determine the area covered by each slope class was carried out using the formula:

Slope class $=$ Pixel pesolution $\times$ Class count

\section{Results and Discussions}

A landslide or landslip is a geological phenomenon which includes a wide range of ground movement, such as rockfalls, deep failure of slopes and shallow debris flows, which can occur in offshore, coastal and onshore environments. Although the action of gravity is the primary driving force for a landslide to occur, there are other contributing factors affecting the original slope stability. Typically, pre-conditional factors build up specific sub-surface conditions that make the area/slope prone to failure, whereas the actual landslide often requires a trigger before being released.

Landslides occur when the stability of a slope changes from a stable to an unstable condition. A change in the stability of a slope can be caused by a number of factors, acting together or alone. Natural causes of landslides in the study area include:

(1) ground-water (pore-water seepage) pressure acting to destabilize the slope, loss or absence of vertical vegetative structure, loss of soil nutrients, and soil structure deterioration (caused by sheet erosion);

(2) erosion of the toe of a slope by stream channel flow;

(3) weakening of a slope through saturation by ting, or heavy rains.

In the study area these factors are aggravated by human activities, which include:

(1) deforestation cultivation of waterleaf and channeling of roadside drains into the stream, which destabilize the already fragile slopes;

(2) the convexity of most of the valley slopes coupled with the termination of drainage channel constructed halfway as well as poor roads and drains maintenance by the community and government have led to the elongation and widening of the large, deep, and awe-inspiring gullies at Dominic Utuk Avenue, near NITEL office in the study area;

(3) vibrations from machinery or traffic;

(4) blasting for gravels and sand quarrying;

(5) earthwork which alters the shape of a slope, or which imposes new loads on an existing slope;

(6) in shallow soils, the removal of deep-rooted vegetation that binds colluvium to bedrock;

(7) construction, agricultural or forestry activities 
(logging) which change the amount of water which infiltrates the soil.

Slope material that becomes saturated with water may develop into a debris flow or mudflow. The resulting slurry of rock and mud may pick up trees, houses and cars, thus blocking bridges and tributaries causing flooding along its path.

Debris flow is often mistaken for flash flood, but they are entirely different processes.

Muddy-debris flows in the study area cause severe damage to structures and infrastructure and often claim human lives. Muddy-debris flows can start as a result of slope-related factors and shallow landslides can dam stream beds, resulting in temporary water blockage. As the impoundments fail, a "domino effect" may be created, with a remarkable growth in the volume of the flowing mass, which takes up the debris in the stream channel. The solid-liquid mixture can reach densities of up to 2 tons $/ \mathrm{m}^{3}$ and velocities of up to $14 \mathrm{~m} / \mathrm{s}$ [12, 13]. These processes normally cause the first severe road interruptions, due not only to deposits accumulated on the road (from several cubic metres to hundreds of cubic metres), but in some cases to the complete removal of bridges or roadways or railways crossing the stream channel.

However, because of compaction of the ground in the built-up (urban) environment, as in the case of the study area, the soils are relatively impermeable and therefore susceptible to the action of sheetwash and gullying.
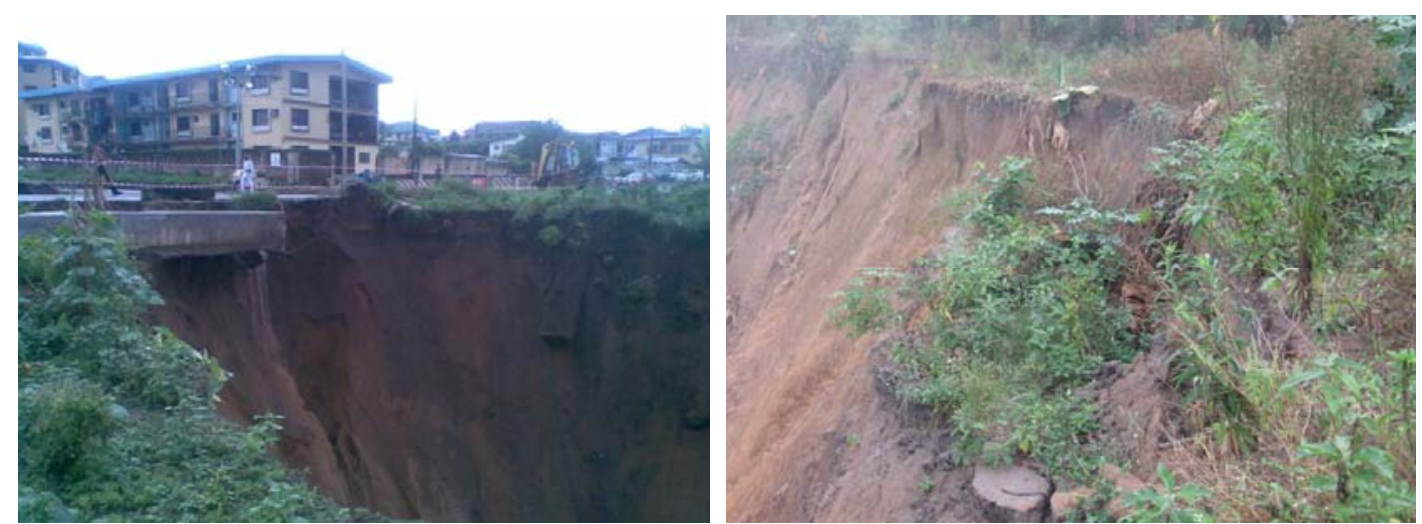

Fig. 4 Landslides posing danger to a hotel complex and other infrastructures.

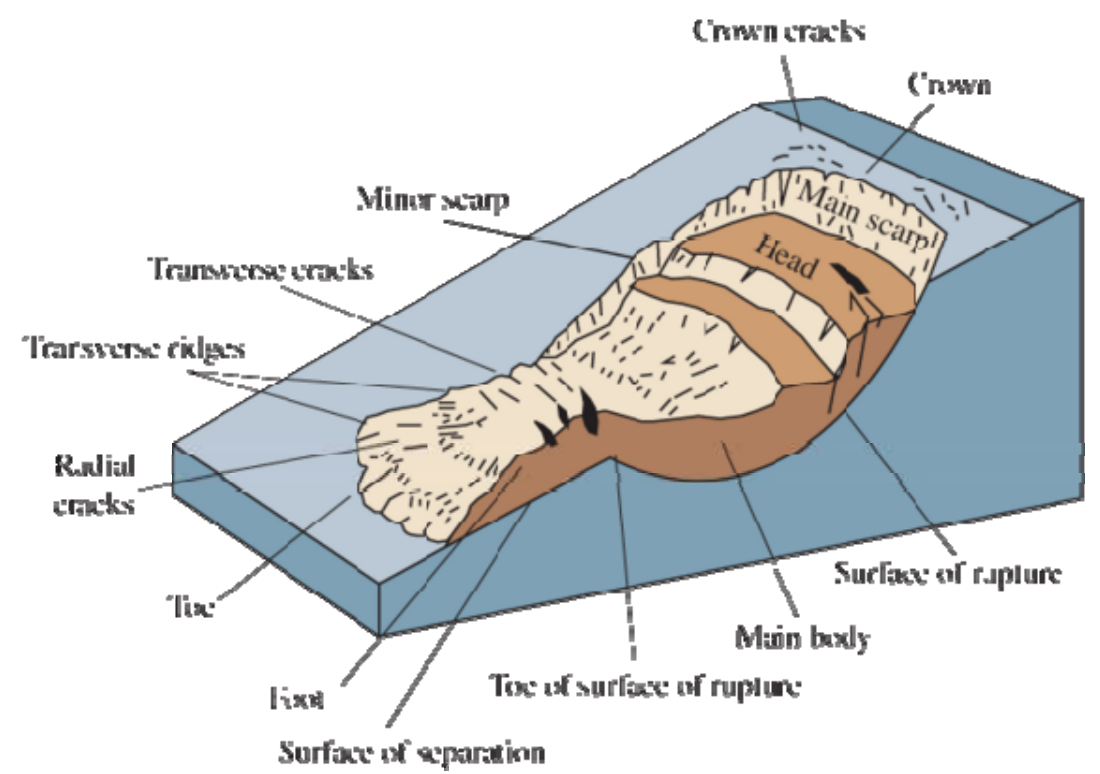

Fig. 5 Ideal model of landslide. 

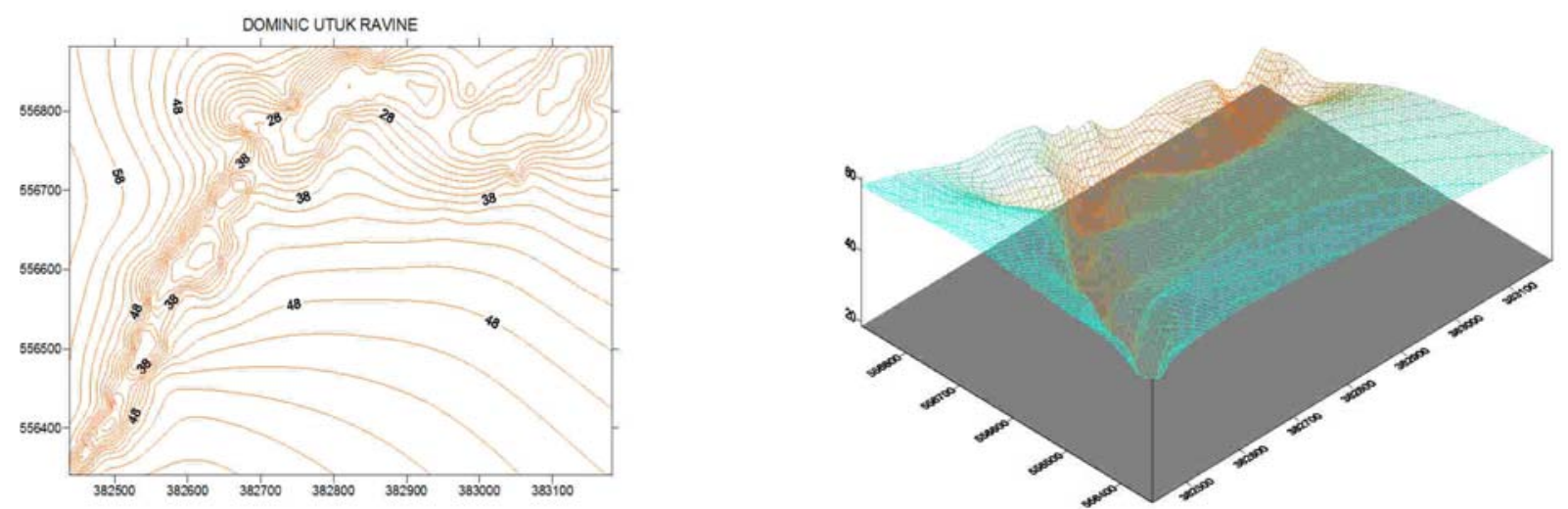

Fig. 6 DEM (Digital Elevation Model) of the study area at Dominic Utuk Avenue.

Source: Ref. [14].

As evident from photographs in the document, the severity of gully erosion is attributable to slope gradient. For instance, field observation showed that in the gully system, the bulk of surface runoff that created gully erosion in the area was generated about $2.4 \mathrm{~km}$ (longest distance travelled by surface runoff) away from the gully site, but becomes concentrated as it approaches the steep slopes near the NITEL buildings (Fig. 3). In fact, the runoff originated from the main roads, about equal distance to the left and right of the pronounced depression in the middle of Dominic Utuk Avenue and routed through the built-up area via the storm drains shown in the picture, down to gully system where it developed into a pond-like feature before exit into 1st order stream, with a base level of $11 \mathrm{~m}$ a.s.l. (above sea level) compared with the highest elevation of $90 \mathrm{~m}$ a.s.l. near Nwaniba road axis.

Further, the slope shapes as revealed by the DEMs of the study gullies are dominantly convex. This implies that overland flow will be generated from all sides of the slope which invariably increase runoff into the gully channels. The DEM for Dominic Utuk Avenue gully system/gully catchment exhibits very steep terrains which ordinarily should encourage intense erosion and flooding in the upslope area where buildings are often inundated by flood water as in Assemblies of God Church and buildings in the neighbor-hood.
Figs. 7 and 8 show the slope map and final landslide susceptibility map of the study area respectively. The result shows that the most susceptible areas to landslides are where the terrain undulation is high. In these areas the impact of rainfall induced flood water is high and slope failures are very predominant. There are also wide spread occurrence of deep and wide gullies in this area, as more and more sloppy grounds cave in after being weakened by the impact of rainfall. Areas that are of average, less or least susceptibility are found mainly in the low lying grounds. These are mostly developed and inhabited areas and human activities contribute to incidences of landslides in the area.

Table 2 shows the different areas of susceptibility and the percentage of the total areas occupied. The table revealed that most susceptible areas occupy about $10.59 \%$ of the area studied or $89,583 \mathrm{~m}^{2}$, while moderately susceptible areas are found in $32.94 \%$ or $278,648 \mathrm{~m}^{2}$ of the study area. Least susceptible areas occupy a total of $56.47 \%$ of the study area or about $477,687 \mathrm{~m}^{2}$ of land. The implications of these results are enormous as the area is heavily populated with extensive network of roads and dense concentration of residential houses, Nitel headquarters, a four star hotel-ENGIM Hotels Ltd, Nigercat Nig Ltd. and Dagson Hotel (shown in Fig. 3). As a result, slope failures and landslides have caused extensive damage with each rainy season. Some do result in loss of lives. 
A questionnaire interview conducted on 100 residents in the neighbourhood of the gully/landslide site to ascertain the effects of soil erosion on the socio-economic life of the people revealed that flooding is the most common (25.74\%) disaster: followed closely by gully erosion and landslide, which are $23.18 \%$ each respectively; sheet/rill erosion had a percentage of $10.90 \%$. The rest $16.99 \%$ did not respond to the question on the type of natural disaster experienced in the study area [15].

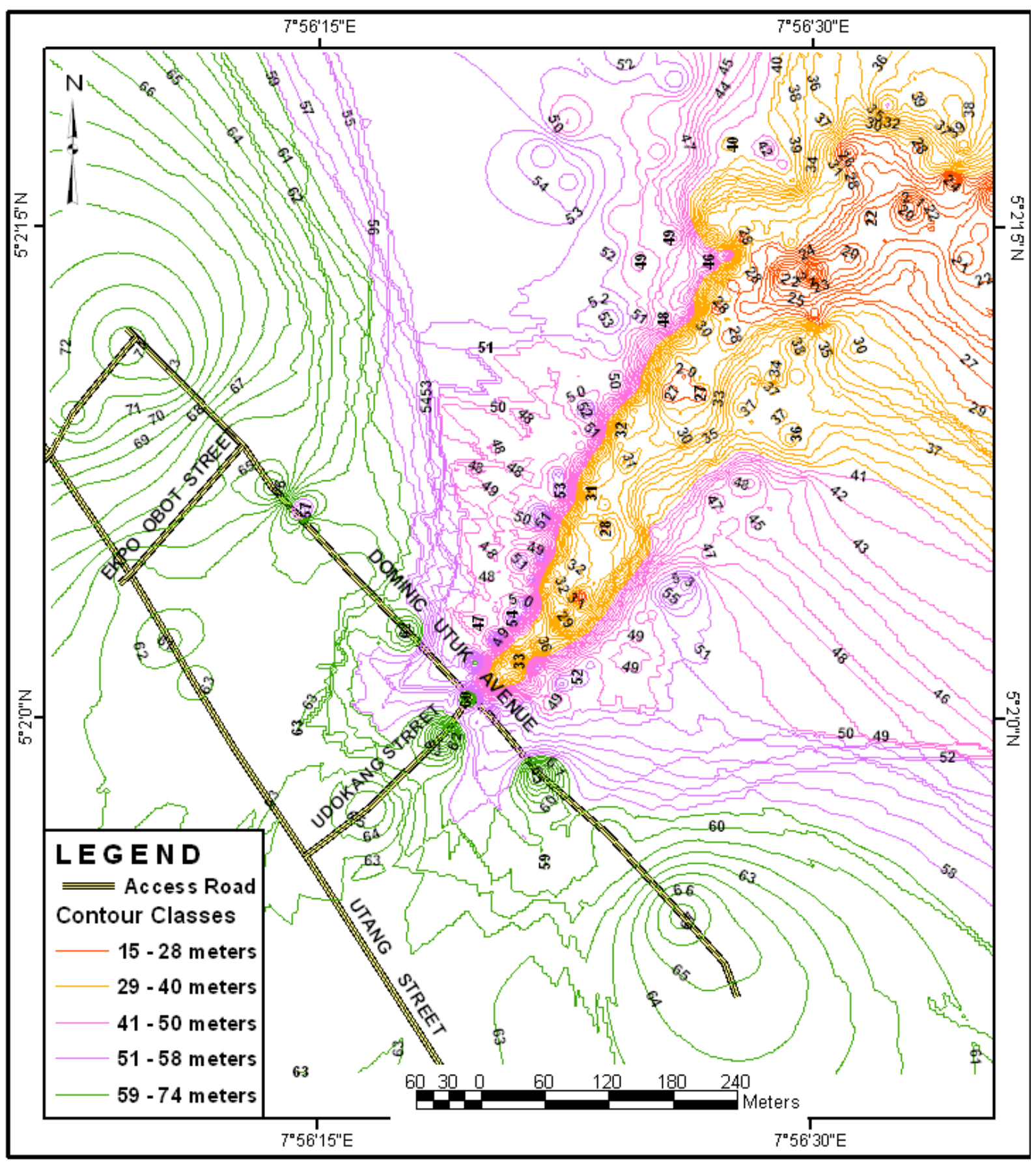

Fig. 7 Contour map of the study area site.

Source: Ref. [14]. 


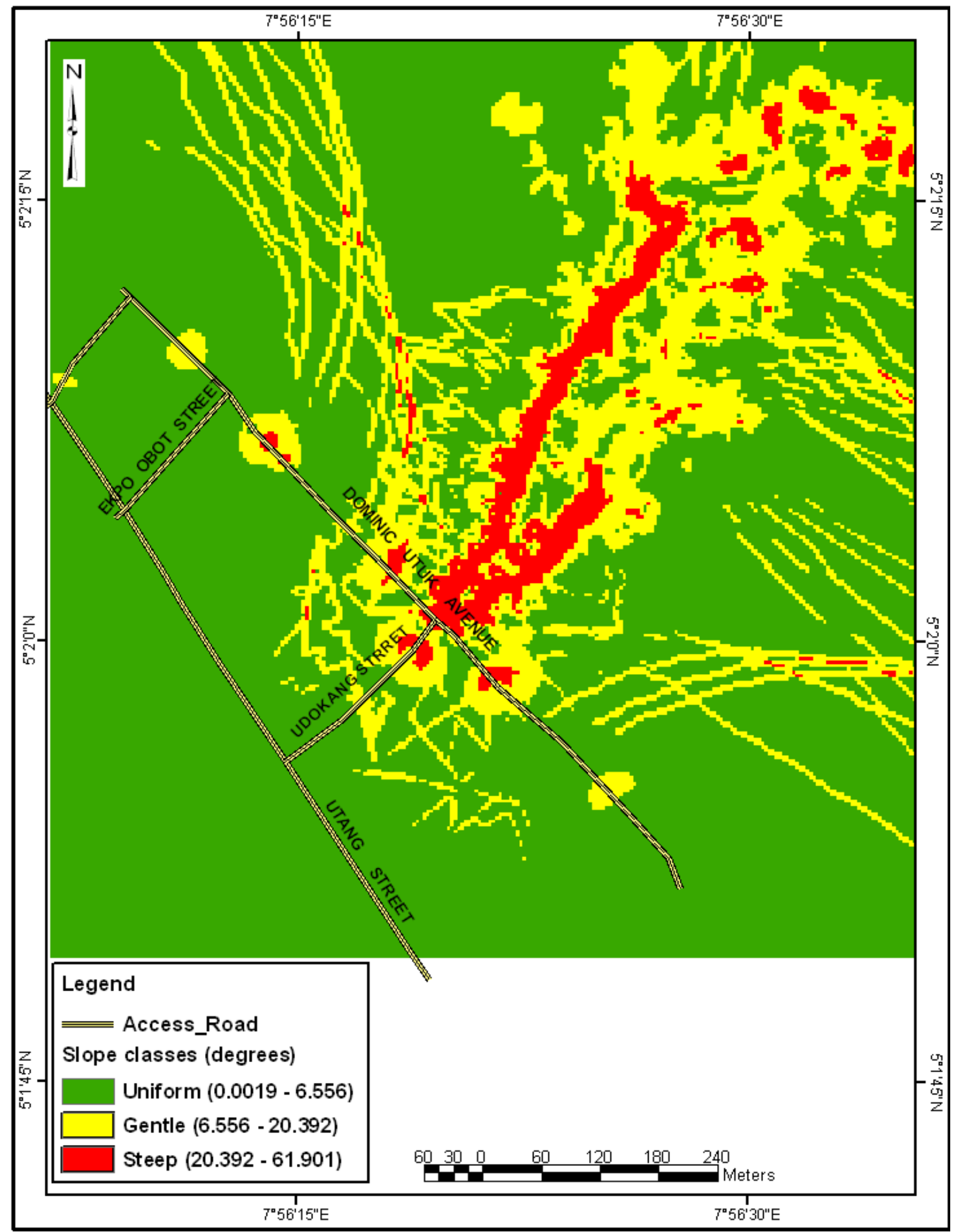

Fig. 8 Landslide susceptibility map of the study area.

Source: Ref. [14]. 
Table 2 Percentage coverage of landslide susceptible areas.

\begin{tabular}{llllrl}
\hline Land susceptibility class & Value (degrees) & Pixel resolution $(\mathrm{m})$ & Class count & Area $\left(\mathrm{m}^{2}\right)$ & Percentage $(\%)$ \\
\hline Least susceptible & $0.0019-6.556$ & $3.52 \times 3.52$ & 38,553 & 477,687 & 56.47 \\
Moderate susceptible & $6.556-20.392$ & $3.52 \times 3.52$ & 22,489 & 278,648 & 32.94 \\
Most susceptible & $20.392-61.901$ & $3.52 \times 3.52$ & 7,230 & 89,583 & 10.59 \\
\hline Total & & & 68,272 & 845,918 & 100 \\
\hline
\end{tabular}

Source: Ref. [14].

\section{Conclusion}

The relevance of this study is that GIS particularly DEM can be used to analyse areas susceptible to landslide for appropriate land management and river basin conservation in the fragile ecology of south eastern Nigeria underlain by the loose and weakly cemented coastal plains sands.

\section{References}

[1] Gao, J., and Lo, C. P. 1995. "Micro-scaled Modelling of Terrain Susceptibility to Landsliding from a DEM: A GIS Approach.” Geocarto International 10 (4): 15-30.

[2] Renwick, W., Brumbaugh, R., and Loeher, L. 1982. "Landslide Morphology and Processes on Santa Cruz Island California.” Geografiska Annaler. Series A, Physical Geography 64 (3/4): 149-59. doi:10.2307/520642. JSTOR 520642.

[3] Igbokwe, J. I., Olisakwe, K. U., Akinyede, J. O, Dang, O. B., and Alaga, T. 2009. "Modelling Landslide Susceptibility in Parts of Southeastern Nigeria with Medium Resolution Remotely Sensed Images.” Geospatial World. Geospatial Comminication Network.

[4] Metternicht, G, Hurni, L., and Gogu, R. 2005. "Remote Sensing of Landslides: An Analysis of the Potential Contribution to Geo-spatial Systems for Hazard Assessment in Mountainous Environments.” Remote Sensing of Environment $98 \quad$ (2-3): 284. doi:10.1016/j.rse.2005.08.004.

[5] Ohlmacher, G. 2003. "Using Multiple Logistic Regression and GIS Technology to Predict Landslide Hazard in Northeast Kansas, USA.” Engineering Geology 69 (3-4):
331. doi:10.1016/S0013-7952(03)00069-3.

[6] Melzner, S., Glade, T., and Bonte-Grapentin, M. 2006. Landslide Susceptibility Analysis Using Remote Sensing Derived Data and GIS Techniques-Navua Catchment, South Viti Levu, Figi Islands.

[7] Schuster, R. L., and Krizek, R. J. 1978. Landslides: Analysis and Control. Washington, D.C.: National Academy of Sciences.

[8] Rohit, K., and Sangram, G. 1996. An Integrated Approach with GIS and Remote Sensing Techniques for Landslide Hazard Zonation.

[9] Fabbri, A. G., Chung, C. F., Cendrero, A., and Remondo, J. 2003. "Is Prediction of Future Landslides Possible with a GIS?” Natural Hazards 30 (3): 487. doi:10.1023/B:NHAZ.0000007282.62071.75

[10] Udosen, C. E. 2008. Gully Erosion in Ikpa River Basin: A Threshold Phenomenon. Lagos: Time Communications.

[11] ESRI (Environmental Systems Research Institute). 2005. "Digital Elevation Model and 3D Features." http://www.support.esri.com/GISDictionary.

[12] Chen, Z. H., and Wang, J. F. 2007. "Landslide Hazard Mapping Using Logistic Regression Model in Mackenzie Valley, Canada.” Natural Hazards 42: 75. doi:10.1007/s11069-006-9061-6.

[13] Lee, S., and Talib, J. A. 2005. "Probabilistic Landslide Susceptibility and Factor Effect Analysis.” Environmental Geology 47 (7): 982. doi:10.1007/s00254-005-1228-z.

[14] Udosen, C. E. October 18-21, 2011. "A Study of Landslide Hazard in South Eastern Nigeria.” Presented at Annual Conference of the Nigerian Association of Hydrological Science, Abuja.

[15] Udosen, C. E. 2011. Technical Report on Dominic Utuk Gully Complex. Submitted to Nigerpet Structures Ltd., Eroflod Projects Ltd. 